\title{
RELIEF AND SEDIMENTS OF NIDA RIVER VALLEY NEAR PIŃCZÓW GAP-SECTION - FIRST RESULTS
}

DOI: https://doi.org/10.18509/AGB217-40145f

UDC: 528.94:551.435.14(438)

\author{
Marcin Frączek $^{1}$, Tomasz Kalicki ${ }^{1}$, Piotr Biesaga ${ }^{2}$, Karolina Walczyńska² \\ ${ }^{1}$ Jan Kochanowski University in Kielce, Institute of Geography and Environmental Sciences, Kielce, Poland, \\ marcinfraczek1987@gmail.com,tomaszkalicki@ymail.com \\ ${ }^{2} J a n$ Kochanowski University in Kielce, Institute of Geography and Environmental Sciences, Student Research \\ Group of Geomorphologists ,Zloty Bażant”, Poland
}

corresponding author:

\begin{abstract}
The study area is located in central Poland in the S part of Nida Basin between two elevations: Umianowice marl monadnock and Pińczów Horst. This is the part of a gap-section of the Nida river near Pińczów. Nida is the 2nd order river, tributary of the Vistula river.

The work aims to recognize the relief and the structure of the Nida valley and to establish the chronology and origin of these structures. The results indicate differentiation in the sedimentation on the wide floodplain and in the vicinity of the riverbed.

On the wide floodplain (more than $2 \mathrm{~km}$ ) between Umianowice and Pińczów, based on aerial photo and digital terrain model, (DTM) we can notice remains of the multichannel river system (probably anastomosing river). Based on the historical maps the changes in the development of the riverbed in this area are visible. Nowadays, in the study section, we can observe the meandering river pattern.The A-B schematic geological cross-section was created based on the series of geological boreholes. Based on the field and laboratory detailed sedimentological analysis we can certainly say that the western part of the A-B profile is significantly different from the eastern part (closer to the river). In the western part, we can distinguish more organic deposits (mostly peaty silts and peats), while in the eastern part sediments are more mineral (mostly sands, sands with gravels and sandy silts). These differences in the geological structure could be caused by the distance from the riverbed and and activity of of fluvial processes.
\end{abstract}

Keywords: Nida Basin, morphodynamic processes, large-radius palaeomeander, anastomosing alluvial plain.

\section{INTRODUCTION}

The natural environment of research area is poorly explored ([1], [2], [3], [4] [5]). According to the physical geographic regionalization of the studied area is located in the Polish Upland province (34), the Little Poland Upland sub-province (342), the

\section{AIM OF THE STUDY AND METHODS}

The study aimed to identify the relief and sediments of the area with the use of many fields, on-desk and laboratory methods. On-desk methods consisted mainly in the query of archival materials and the analysis of aerial photos and thematic maps (Fig. 2). During fieldworks, several boreholes were made (Fig. 3) which allowed for detailed recognition of the forms occurring in the field and, as a result, for the creation of a geomorphological map (Fig. 4).
Nida Basin macroregion (342.2) in the central part of the Nida Valley mezoregion (342.25), on the border with the Jędrzejów Plateau (324.21) and the Połaniec Basin (342.28) [1], (Fig.1).

Geological mapping of the Quaternary sediments was performed, which allowed determining the origin and stratigraphy of sediments in the studied area. In the laboratory, several methods were used. Grain size analysis based on sieve method and laser diffraction, loss of ignition (LOI), analysis of calcium carbonate $(\mathrm{CaCO} 3)$ content (Scheibler method) and the $\mathrm{pH}$ value were determined using the potentiometric method. 


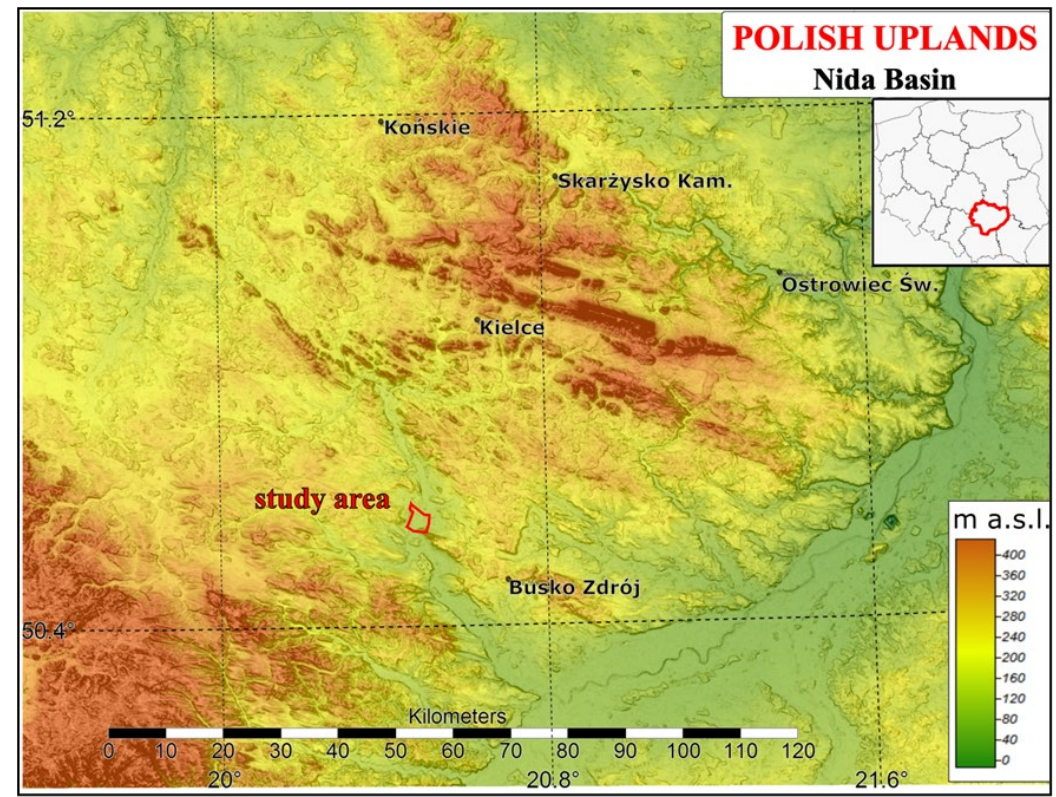

Figure 1. Digital terrain model (DTM) of the Holy Cross Mts. region

\section{GEOLOGICAL AND GEOMORFOLOGICAL BACKGROUND}

The study area is located in the Nida Basin mesoregion, which is a kind of synclinorium between the Kraków-Częstochowa Upland in the west and the Kielce Upland in the north-east [1]. The Nida Basin is filled mainly with Mesozoic formations [2] which were dislocated and covered by the younger Tertiary sediments: marls, limestones, and gypsums, in which karst phenomena developed intensively.

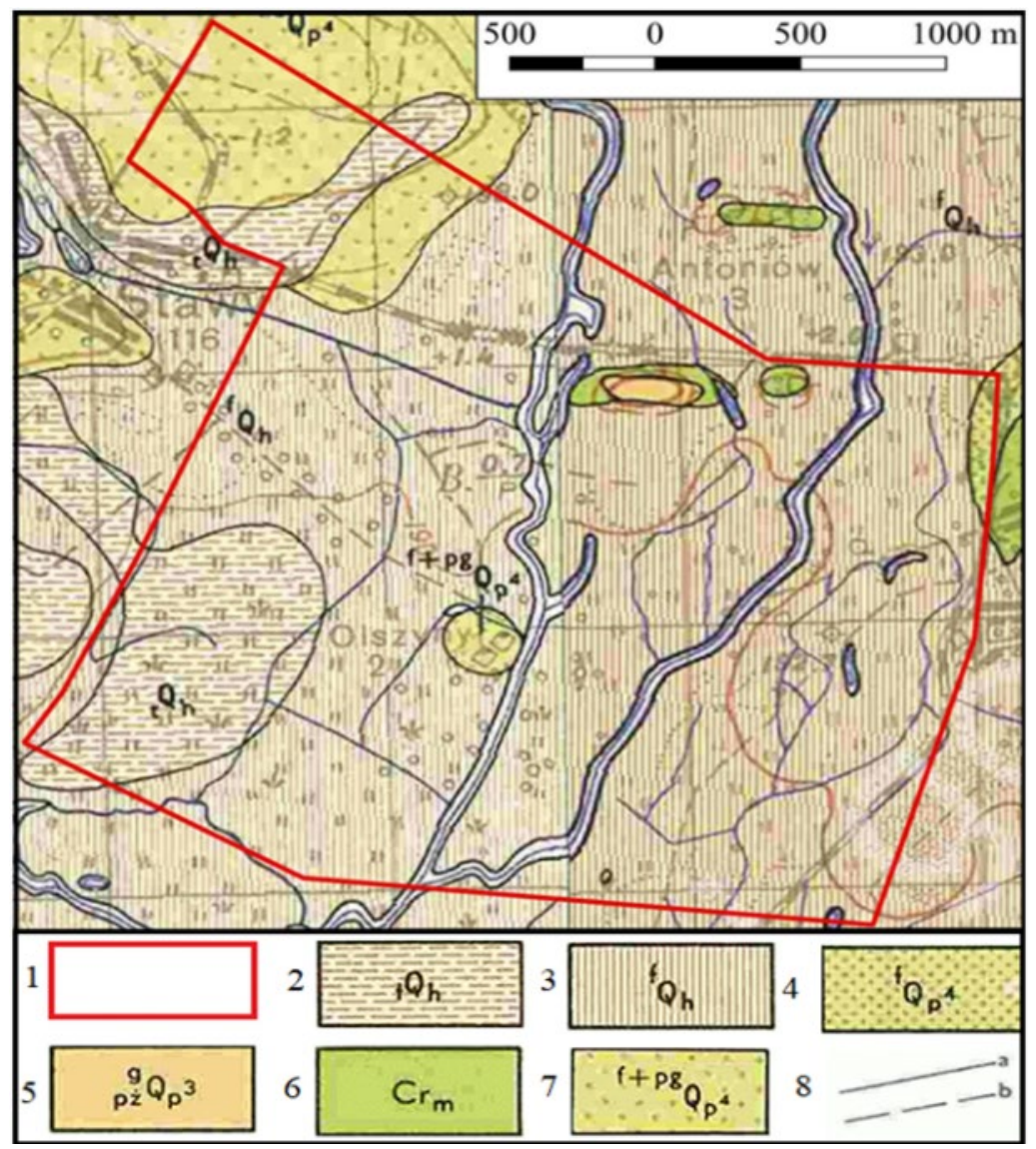

Figure 2. Geological map of the research area based on Detailed Geological Maps of Poland - Jędrzejów [7] and Pińczów [8] sheets 1:50 000; 1 - research area, 2 - peat and peat bogs, 3 - sands, gravels and river meadows, 4 - sands of accumulation terraces, 5 - sands and gravels of glacial accumulation with boulders, 6 - marly rocks, marls, sandstones and geoses, 7 - river-periglacial sands, 8 - boundaries of geological strata; a certain, $b$ - presumed. 
The oldest formations from the Upper Cretaceous Maastricht (marly rocks, marls, sandstones and geoses [2]) formed an erosion socle of the Pleistocene terraces remnants in the flood plain (Fig. 2, 4). The sands and gravels with boulders of the younger terrace were accumulated during the Middle Polish Glaciation (about 440-130 ka [6]). The youngest sediments within the study area came

\section{RESULTS}

The width of study section of the Nida river valley is about $2 \mathrm{~km}$. Two terraces occurred here. The upper terrace is preserved on the right side of the valley. Within the flood plain occurs several erosion remnants of younger terrace.

We can distinguish two levels of floodplain older (cross-section A-B) and younger (outcrop C 1) (Fig. 4). Within older floodplain the schematic geological cross-section A-B was created based on from the Subboreal. Their thickness increases in the southern part of Nida Basin [5] and they are limited to the areas of contemporary river valleys [2]. Sands, gravels, and river marshes, which cover almost the entire research area (Fig. 2), were created as a result of Nida River accumulation. Peats and peaty silts, with the thickness of 1-2 m, represent the Holocene (Fig. 2, 6).

the series of geological boreholes (location Fig. 3, $4,5)$. In their western part, more organic deposits occurred (mostly peaty silts and peats), while in the eastern part (closer to the river) sediments are more mineral (mostly sands, sands with gravels and sandy silts) (Fig. 6). The most characteristic for the western part is the geological borehole Stawy 2 and for the eastern part borehole Stawy 51 .

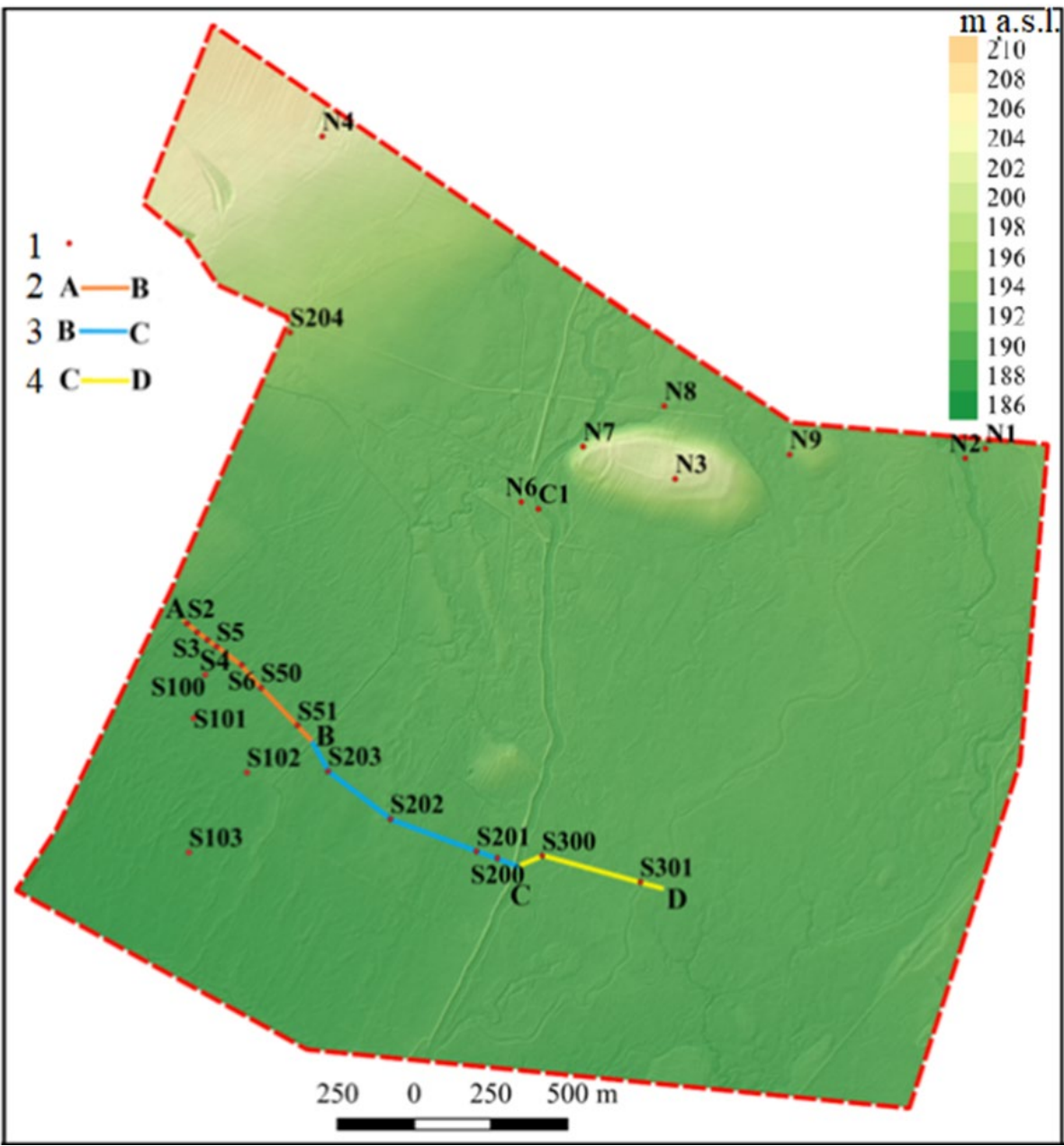

Figure 3. Location of geological boreholes and cross-section lines on DTM 1 - geological boreholes, 2 - A-B cross-section line, 3 - B-C cross-section line, 4 - C-D cross-sectional line.

Four members could be distinguished in the geological core Stawy 2 (Fig. 6 - Stawy 2). The lowest member (I) is built of silty sands (Mz above $4 \phi)$. The second member (II) is built of peaty silts. Organic matter content increases upward from 12 to $38 \%$. The layer of sands (about $5 \mathrm{~cm}$ thick) occurs in the most upper part of this member. The third member (III) is intercalated of silty sands and coarse/medium sands. The sediments of this member are poorly sorted in the lower part and medium sorted in the upper. Four members could be distinguished in the geological core Stawy 2 
(Fig. 6 - Stawy 2). The lowest member (I) is built of silty sands (Mz above $4 \phi$ ). The second member (II) is built of peaty silts. Organic matter content increases upward from 12 to $38 \%$. The layer of sands (about $5 \mathrm{~cm}$ thick) occurs in the most upper part of this member. The third member (III) is intercalated of silty sands and coarse/medium sands.

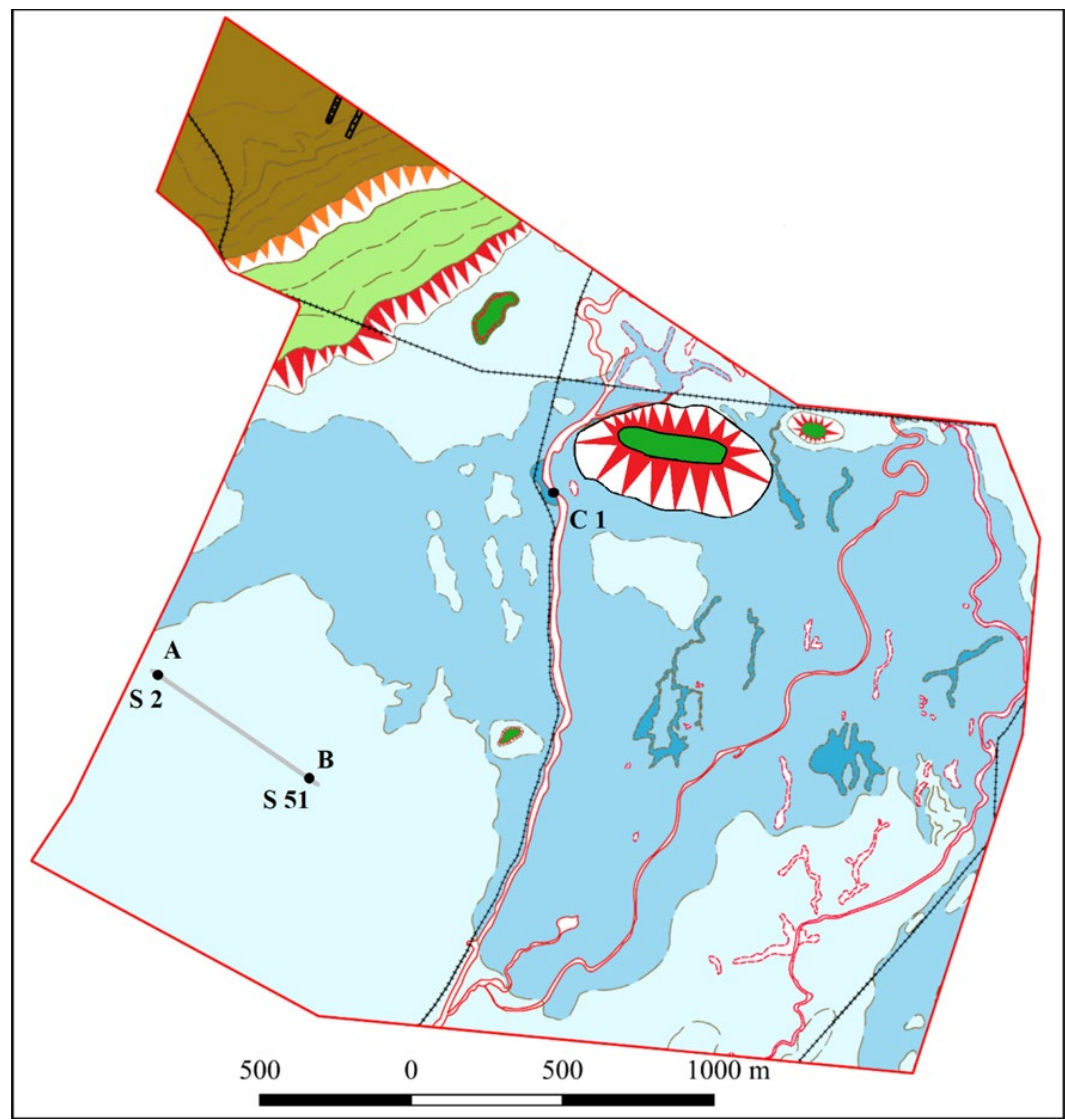

Figure 4. Geomorphological map of the research area; 1 - research area, 2- valley slope, 3 - Pleistocene terrace I, 4 - Pleistocene terrace II, 5 - Holocene floodplain: older cut and fill, 6 - Holocene floodplain: younger cut and fil,

7 - bottom of abandoned channel (organic sediments), 8 - alluvial riverbed, 9 - Holocene abandoned channels,

10 - Holocene edges, 11 - Pleistocene edges, 12 - anthropogenic embankment, 13 - anthropogenic edges,

14 - anthropogenic sunken lane (hollow way), 15 - A-B cross-section line, 16 - No. of geological boreholes.

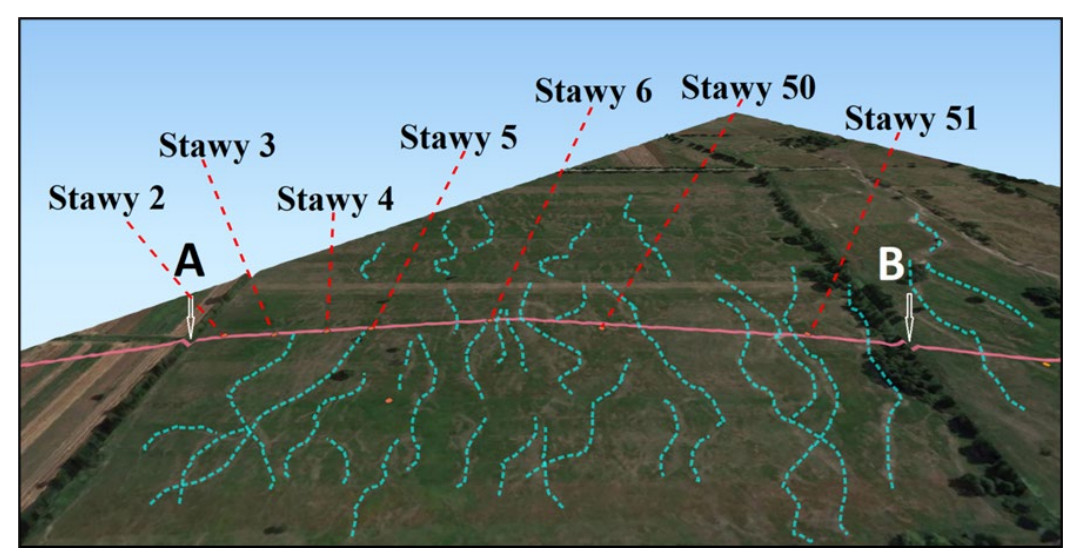

Figure 5. 3D model of Nida floodplain on A-B cross-section distance with remnants of the anastomosing river system

The sediments of this member are poorly sorted in the lower part and medium sorted in the upper. The fourth member (IV) includes peaty silts with an organic matter content from $4 \%$ to $20 \%$. At a depth of up to $29 \mathrm{~cm}$, they are cut with a $10 \mathrm{~cm}$ thick layer of sand. The sand is bad sorted (Fig. 6). The geological core Stawy 51 consists of four members above sandy gravel channel deposits. The first member (I) is built of silty sands bad sorted. The second one (II) is silty peats and peaty silts with organic matter content ranging from 22 to $35 \%$. The third member (III) is mineral deposits (very bad and bad sorted) - silty sands in the most lower and most upper parts and sands in the middle part. The fourth 
member (IV) includes peaty silts with organic matter content from 10 to $18 \%$ (Fig. 6).

The sediments of profile $\mathrm{C} 1$ represents the structure of younger floodplain. There is a typical meandering river alluvium with channel deposits in its bottom and overbank deposits (levee) in the upper part.

\section{DISCUSSION AND CONCLUSIONS}

Remnants of the Pleistocene terrace, that were preserved on the left bank of the valley [10] (Fig. 2, 4) are effect of an intensive deep erosion at the end of Pleniglacial occurred in many Central European valleys of different river orders [11 and references therein].

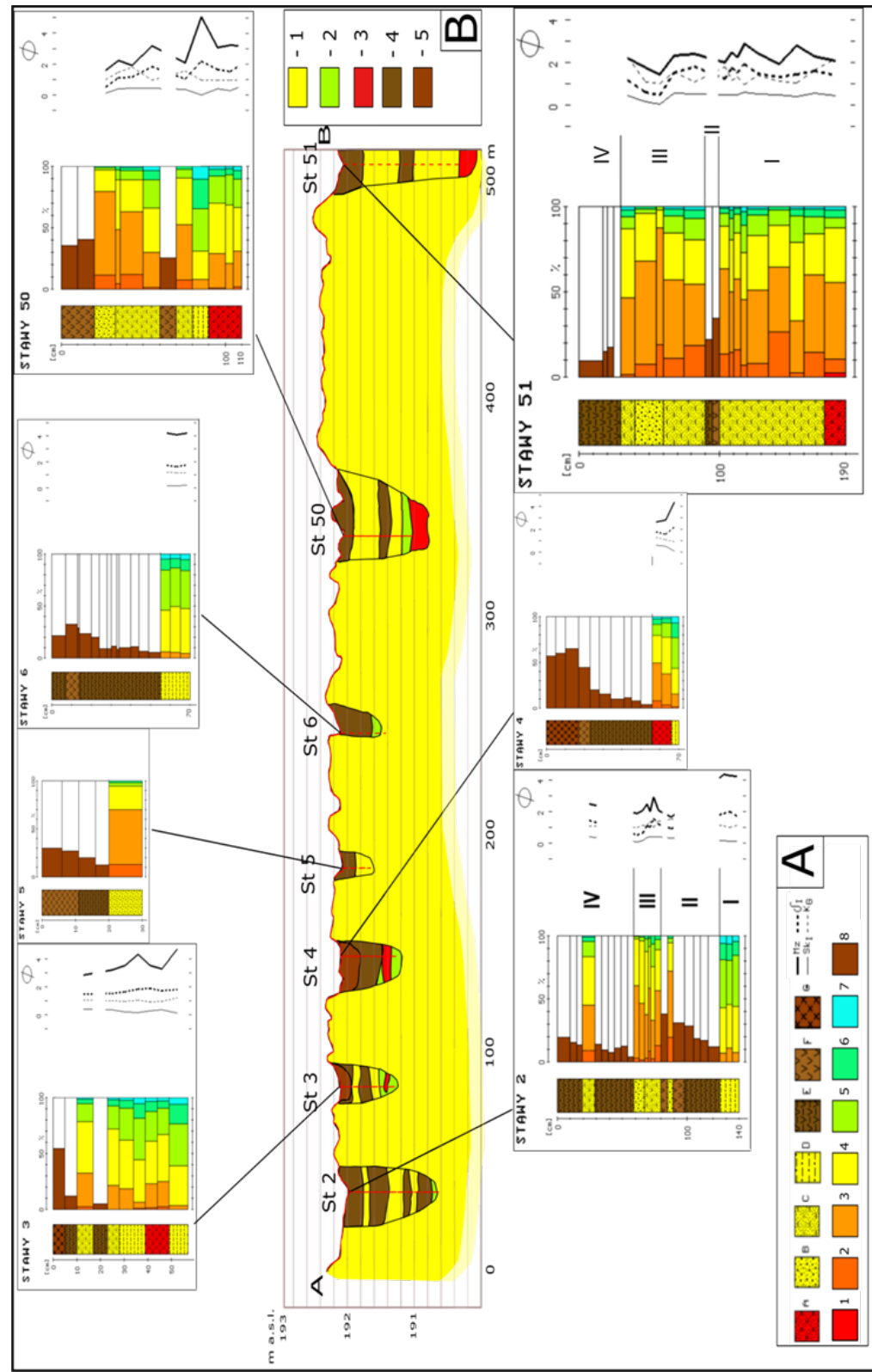

Figure 6. Schematic section A-B (location see Fig. 4, 7) across the Nida floodplain, lithology, grain size and FolkWard's distribution parameters of selected profiles ([2] changed)

A: Lithology: A - gravels, B - coarse/medium sands, C - silty sands, D - sandy clay/silts, E - peaty silts, F- silty

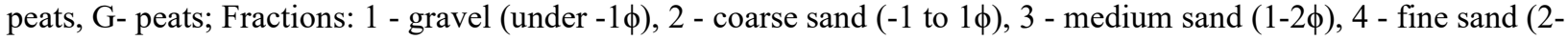

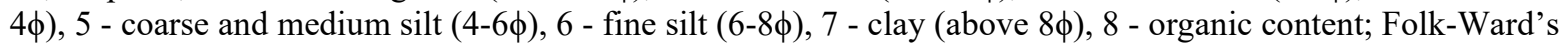
distribution parameters: $\mathrm{Mz}$ - mean diameter, $\delta 1$ - standard deviation (sorting), Skl - skewness, KG - kurtosis. Explanation legend B: 1- coarse/medium sand, 2- sandy silt, 3- sand with single gravels, 4- peaty silts, 5- peats.

Based on the collected materials and mostly on information from other river systems $[12,11$ and references therein], we can preliminarily assume that initially, in the Late Glacial, the Nida was a braided river, then, as a result of the climate change, it was transformed into a river with macromeanders. Upstream of the described gapsection, on the left bank of the Nida floodplain, 
there are visible palaeomeanders (probably largeradius - not clear yet). Within the floodplain occurs several elevations which were earlier considered as dunes [9]. However, there are the erosion remnants of younger terrace. It could be connected with the lateral migration of the Late Glacial large meanders when the valley bottom widened and undercut terrace fragments that were preserved as meandering hills just like it took place in the Czarna Nida River valley [12]. Oxbow lakes visible in the relief of the floodplain reflect lateral migration of the Nida riverbed also during the Holocene.

The peaty plain marked by [9] does not exist in the valley bottom. Geomorphological mapping allowed to distinguish two levels (cut and fill) of the floodplain (Fig. 4).

The older one (cross-section A-B) was formed by an anastomosing river. These small depressions, visible in the relief and on the aerial photo and DTM models, are probably remnants of the anastomosing river system [13]. The geological cross-section confirms the existence of the remnants of the multichannel system (anastomosing).

The abandoned channels are separated by sandy ,islands”. In the palaeochannels, sandy sediments were deposited and during the sedimentological hiatus, organic sediments were deposited (Stawy 2 member III). Sometimes (in short periods) took place a reactivation of this palaeochannels. During the flood episodes badly sorted sands were deposited (Stawy 2 member III and IV, Stawy 51 member I and III). Closer to the presentday riverbed the mineral sediments in the paleochannel fill prevail while organic sediments dominate as the distance increases.

The similar remnants of multichannel patterns are preserved in relief of many sections of the Czarna Nida River valley (a left tributary of the Nida) and they were active in the Early (PB-BO) and Late Holocene (SA-2) [12].

The younger cut and fill of Nida are connected with the meandering river (outcrop C 1) where on the channel sediments we can find overbank deposits (levee). Upstream the described gap-section, on the left bank of the Nida floodplain, there are visible two old Nida River branches. Their presence could be caused by an anthropogenic or the natural processes [13]. Within the research area, there are several different ages sequences, which were formed by a river with different channel pattern. These episodes have not yet been precisely identified and require further detailed research.

\section{REFERENCES}

[1] Kondracki J., Geografia regionalna Polski, PWN, 2012.

[2] Łyczewska J., Objaśnienia do szczegółowej mapy geologicznej Polski,1:50 000, Arkusz 883 Jędrzejów, Wydawnictwo geologiczne, 1971.

[3] Pożaryski W., Rozwój poglądów na tektonikę Niżu Polskiego. W: Budowa geologiczna Polski, 4 - Tektonika, part 1, 35-44, 1974.

[4] Stupnicka E., Geologia regionalna Polski, Wydawnictwo Geologiczne, Warszawa 1989.

[5] Kupczyk E., Biernat T., Ciupa T, Kasprzyk A. and Suligowski R., Zasoby wodne dorzecza Nidy. Wyd. WSP, Kielce, p. 175, 1994.

[6] Lindner L., O podziale klimatostratygraficznym kompleksu środkowopolskiego w plejstocenie Polski, Przegląd Geologiczny, 36-45, 2012.

[7] Łyczewska J., Szczegółowa mapa geologiczna Polski arkusz 883 Jędrzejów w skali 1:50000, Wydawnictwa Geologiczne 1972.

[8] Senkowicz E., Szczegółowa mapa geologiczna Polski arkusz 884 Pińczów w skali 1:50000, Wydawnictwa Geologiczne 1958.

[9] Mityk J., Zarys rzeźby terenu badanego odcinka zlewni Nidy, Studia Kieleckie 1/61, Kielce: 21-30, 1989.

[10] Walczyńska K., Tomczyk M., Geomorphological and morphodynamic mapping of the Nida valley near Stawy. 24 Kvarter, 30 listopada 2018 Brno, 69, 2018.

[11] Kalicki, T. Zapis zmian klimatu oraz działalności człowieka i ich rola w holoceńskiej ewolucji dolin środkowoeuropejskich (Reflection of climatic changes and human activity and their role in the Holocene evolution of Central European valleys). Prace Geograficzne 204, 1-348, 2006.

[12] Krupa J., Naturalne i antropogeniczne procesy kształtujące dno doliny Czarnej Nidy w późnym vistulianie i holocenie, Folia Quaternaria 81, 1-174, 2013.

[13] Walczyńska K., Rzeźba i osady równiny zalewowej Nidy w okolicach Umianowic. Typescript of Bacalar work. UJK archives, Kielce, 2019 